\title{
PROTOTIPE PENGERING BAHAN BAKU DAN PRODUK BIOPELET DITINJAU DARI VARIASI KECEPATAN UDARA TERHADAP JUMLAH PANAS $\mathrm{H}_{2} \mathrm{O}$ DI UDARA
}

\author{
Herlin Sumarna $^{1)}$ dan Hasan Basri ${ }^{2)}$ \\ ${ }^{1,2}$ Program Studi Magister Teknik Mesin, Jurusan Teknik Mesin, Fakultas Teknik, Universitas Sriwijaya \\ 1,2 Jalan Srijaya Negara, Palembang, 30139 \\ E-mail: herlindarman187@gmail.com ${ }^{1)}$, hasan_basri@unsri.ac.id ${ }^{2)}$
}

\begin{abstract}
ABSTRAK
Penggunaan energi fosil bahan bakar minyak bumi dan batubara masih mendominasi sehingga pemilihan biomassa sebagai sumber energi renewable merupakan pemilihan yang tepat. Salah satu produksi bahan bakar dari biomassa adalah biopelet. Dalam tahapan proses pembuatan biopelet salah satunya adalah pengeringan. Tujuan penelitian ini untuk mengetahui pengaruh kecepatan udara pengering terhadap jumlah panas $\mathrm{H}_{2} \mathrm{O}$ di udara yang paling besar, dan nilai kalor serta nilai kadar air produk biopelet. Prototipe pengering skala laboratorium pada penelitian ini memiliki fungsi untuk mengurangi kadar air bahan baku dan produk biopelet. Bahan baku biomassa hasil pengeringan akan dijadikan biopelet, sehingga digunakan oven pengering dengan suplai panas dari furnace. Dalam penelitian diambil variabel tetap antara lain perbandingan campuran bahan baku, waktu pengeringan, dan temperatur pengeringan sedangkan variabel tak tetap yaitu variasi kecepatan udara. Dari penelitian tersebut banyaknya $\mathrm{H}_{2} \mathrm{O}$ yang teruapkan dan panas $\mathrm{H}_{2} \mathrm{O}$ di udara yang paling besar pada kecepatan udara $6 \mathrm{~m} / \mathrm{s}$. Dari massa $\mathrm{H}_{2} \mathrm{O}$ teruapkan sebesar 23,5 gr dan panas $\mathrm{H}_{2} \mathrm{O}$ di udara sebesar 264,55 grcal di analisa kadar air dan nilai kalor produk biopelet. Nilai kadar air didapatkan sebesar 6,47\% dan nilai kalor sebesar 4655,0668 cal/gr telah memenuhi standar SNI 8021-2014.
\end{abstract}

Kata Kunci: energi fosil, kecepatan udara, panas $\mathrm{H}_{2} \mathrm{O}$, kadar air, nilai kalor

\section{PENDAHULUAN}

Beberapa tahun terakhir ini energi merupakan persoalan besar yang berdampak besar terhadap perekonomian dunia. Hal ini dipicu oleh meningkatnya pertambahan penduduk, tingginya biaya eksplorasi dan sulitnya mencari sumber cadangan minyak serta banyaknya tuntutan masyarakat dunia tentang emisi karbon gas buangan (Mahdie dkk., 2016)

Pemakaian energi di Indonesia masih didominasi penggunaan energi berbasis fosil terutama bahan bakar minyak bumi dan batu bara. Apabila dalam waktu dekat tidak ditemukan sumber-sumber energi baru yang signifikan pada tahun 2046 mendatang dikhawatirkan Indonesia akan mengalami defisit energi. Penggunaan energi baru dan terbarukan harus menjadi perhatian utama pemerintah Indonesia tidak hanya sebagai upaya untuk mengurangi pemakaian energi fosil melainkan juga untuk mewujudkan energi bersih atau ramah lingkungan (Jaelani, 2017)

Semakin tinggi pertumbuhan ekonomi suatu daerah maka semakin meningkat pula penggunaan konsumsi energi pada daerah tersebut. Hal ini dikarenakan setiap aktifitas masyarakatnya membutuhkan energi, sedangkan disisi lain sumber energi semakin menipis, sebagaimana halnya energi yang dipakai setiap hari. Semakin berkurang sumber energi tersebut, maka akan menyebabkan krisis energi diseluruh Indonesia. Kondisi ini terjadi dikarenakan permintaan energi yang semakin meningkat, sedangkan ketersediaan jumlah energi semakin sedikit (Kartika, 2017). Untuk mengatasi permasalahan tersebut dengan menggunakan energi alternatif salah satunya yaitu energi biomassa dapat dimanfaatkan sebagai pengganti bahan bakar fosil.

Sumber daya biomassa di Indonesia dapat diperoleh dari limbah pertanian, seperti: produk samping kelapa sawit, penggilingan padi, plywood, ampas kelapa, pabrik gula, kakao, tongkol jagung dan limbah pertanian lainnya (Lamanda dkk., 2015).

Biomassa yang berasal dari limbah hasil pertanian dan kehutanan merupakan bahan yang tidak berguna, tetapi dapat dimanfaatkan menjadi sumber energi bahan bakar alternatif (Utami, 2017), salah satunya dengan mengubahnya menjadi biopelet. Pada umumnya, biopelet yang dihasilkan mempunyai diameter 8-11 mm dan panjang 15-20 mm. Penambahan perekat yang digunakan pada proses pembuatan biopelet yaitu $0,5-5 \%$ sedangkan ukuran mesh yang digunakan ialah ukuran 40-60 mesh (Mahdie dkk., 2016).

Guna memanfaatkan biopelet sebagai sumber energi terbarukan, biopelet harus mengalami proses pengolahan terlebih dahulu sebelum dapat digunakan sebagai sumber energi. Pada proses pengolahan biopelet, pengeringan merupakan salah satu tahap yang sangat penting untuk menghasilkan kualitas bahan bakar biomassa yang baik. Pengeringan tersebut bertujuan untuk mengurangi 
kandungan air yang terdapat di dalam biomassa dan meningkatkan nilai kalor dari biomassa tersebut.

Proses pengeringan merupakan proses perpindahan panas dari sebuah permukaan benda sehingga kandungan air pada permukaan benda berkurang. Perpindahan panas dapat terjadi karena adanya perbedaan temperatur yang signifikan antara dua permukaan. Perbedaan temperatur ini ditimbulkan oleh adanya aliran udara panas di atas permukaan benda yang akan dikeringkan yang mempunyai temperatur lebih dingin. Aliran udara panas merupakan fluida kerja bagi sistim pengeringan. Komponen aliran udara yang mempengaruhi proses pengeringan adalah kecepatan, temperatur, tekanan, dan kelembaban relatif (Syahrul dkk., 2018)

Salah satu jenis alat pengering adalah tipe Rotary dryer atau bisa disebut drum dryer merupakan alat pengering yang berbentuk sebuah drum dan berputar secara kontinyu yang dipanaskan dengan tungku atau gasifier. Rotary dryer sudah sangat dikenal luas di kalangan industri karena proses pengeringannya jarang menghadapi kegagalan baik dari segi output kualitas maupun kuantitas. Namun sejak terjadinya kelangkaan dan mahalnya bahan bakar minyak dan gas, maka teknologi rotary dryer mulai dikembangkan untuk berdampingan dengan teknologi bahan bakar substitusi seperti burner, batubara, gas sintesis dan sebagainya.Pengering rotary dryer biasa digunakan untuk mengeringkan bahan yang berbentuk bubuk, granula, gumpalan partikel padat dalam ukuran besar. Pemasukkan dan pengeluaran bahan terjadi secara otomatis dan berkesinambungan akibat gerakan vibrator, putaran lubang umpan, gerakan berputar dan gaya gravitasi. Sumber panas yang digunakan dapat berasal dari uap listrik, batubara, minyak tanah dan gas (Zikri dkk., 2015)

Secara umum, alat rotary dryer terdiri dari sebuah silinder yang berputar di atas sebuah bearing dengan kemiringan yang kecil menurut sumbu horisontal, rotor, gudang piring, perangkat transmisi, perangkat pendukung, cincin meterai, dan suku cadang lainnya. Panjang silinder biasanya bervariasi dari 4 sampai lebih dari 10 kali diameternya (bervariasi dari 0,3 sampai $3 \mathrm{~m}$ ). Feed padatan dimasukkan dari salah satu ujung silinder dan karena rotasi, pengaruh ketinggian dan slope kemiringan, produk keluar dari salah satu ujungnya. Pengering putar ini dipanaskan dengan kontak langsung gas dengan zat padat atau dengan gas panas yang mengalir melalui mantel luar, atau dengan uap yang kondensasi di dalam seperangkat tabung longitudinal yang dipasangkan pada permukaan dalam selongsong

Udara merujuk kepada campuran gas yang terdapat pada permukaan bumi. Udara bumi yang kering mengandung $78 \%$ nitrogen, dan $21 \%$ uap air, karbon dioksida, dan gas-gas lain. Kandungan elemen senyawa gas dan pertikel dalam udara akan berubah dengan ketinggian dari permukaan tanah. Demikian juga massanya, akan berkurang seiring dengan ketinggian. Semakin dekat dengan lapisan troposfer, maka udara semakin tipis, sehingga melewati batas gravitasi bumi, maka udara akan hampa sama sekali. Psikometrik merupakan suatu bahasan tentang sifat-sifat campuran udara dengan uap air, mempunyai arti yang sangat penting dalam pengondisian udara karena udara pada atmosfir merupakan pencampuran antara udara dan uap air (Stefanus \& Kosasih, 2014).

Kelembaban udara berpengaruh terhadap proses pemindahan uap air. Apabila kelembaban udara tinggi, maka perbedaan tekanan uap air di dalam dan di luar bahan menjadi kecil sehingga menghambat pemindahan uap air dari dalam bahan ke luar. Pengontrolan suhu serta waktu pengeringan dilakukan dengan mengatur kotak alat pengering dengan alat pemanas, seperti udara panas yang dialirkan ataupun alat pemanas lainnya. Suhu pengeringan akan mempengaruhi kelembaban udara di dalam alat pengering dan laju pengeringan untuk bahan tersebut. Pada kelembaban udara yang tinggi, laju penguapan air bahan akan lebih lambat dibandingkan dengan pengeringan pada kelembaban yang rendah (Pradipta \& Kosasih, 2014).

Dalam sektor pertanian sistem pengeringan yang umum digunakan adalah tenaga surya. Pada sistem tenaga surya ini, bahan diekspos ke sinar surya secara langsung maupun tidak langsung. Uap air yang terjadi dipindahkan dari tempat pengeringan melalui aliran udara (Syahrul dkk., 2018). proses pengeringan bahan baku dalam pembuatan biopelet dilakukan menggunakan sinar matahari sebelum diolah menjadi biopelet. Adapun proses pengeringan dengan menggunakan sinar matahari (full sun drying) mempunyai banyak kekurangan, yaitu dalam proses pengeringannya membutuhkan waktu yang tidak pasti karena tergantung pada keadaan cuaca dan memerlukan area yang cukup luas untuk pengringan yang merata.

Sehubungan dengan itu, maka ingin dibuat alat pengering tipe putar yang dikombinasi dengan oven, dimana pengering tipe digunakan untuk mengurangi kadar air pada bahan baku dan oven digunakan untuk mengurangi kadar air pada produk biopelet. Saat proses pengeringan terdapat factor yang mempengaruhi, salah satunya kecepatan volumetric udara pengering yang dapat mempengaruhi hasil pengeringan (Syahrul dkk., 2018). Oleh karena itu, penulis melakukan pengeringan bahan baku biopelet dengan memvariasikan kecepatan udara pemanas untuk mengetahui kadar air paling tinggi yang teruapkan ke udara dengan tipe pengering putar (rotary dryer). Selain mengetahui massa air dalam udara, penelitian ini juga bertujuan untuk mengetahui energi panas $\mathrm{H}_{2} \mathrm{O}$ yang teruapkan, selanjutnya dilakukan pencetakan biopelet dengan bahan baku yang memiliki $\mathrm{H}_{2} \mathrm{O}$ paling tinggi di udara. Biopelet yang telah dicetak akan di analisa kadar air dan nilai kalor yang mengacu pada SNI 8021-2014.

\section{RUANG LINGKUP}

Ruang lingkup rancang bangun alat pengering sebagai pengering bahan baku biopelet yang 
dikombinasikan dengan oven sebagai pengering biopelet untuk mengetahui pengaruh variasi kecepatan udara pengering terhadap jumlah panas $\mathrm{H}_{2} \mathrm{O}$ di udara paling besar dan menganalisa nilai kalor serta nilai kadar air produk biopelet dengan perbandingan bahan baku konstan yaitu $75 \%$ ampas kelapa dan 25\% tongkol jagung.

\section{BAHAN DAN METODE}

Berikut disajikan bahan dan metode terkait dengan penelitian ini

\subsection{Bahan Baku}

Salah satu biomassa yang digunakan sebagai bahan baku untuk membuat biopelet adalah tongkol jagung. Ketersediaan tongkol jagung sangat melimpah, hal ini dikarenakan tongkol jagung merupakan limbah dari pertanian yang tidak dimanfaatkan secara maksimal, sehingga tongkol jagung sangat berpotensi untuk dijadikan sebagai bahan baku piopelet. Menurut Badan Pusat Statistik Sumatera Selatan (2015), produksi jagung pada tahun 2015 mencapai 289.007 ton dengan luas lahan 14,36 ribu ha. Penggunaan tongkol jagung untuk keperluan bahan bakar sekitar $90 \%$ sedangkan limbah batang dan daun sekitar $30 \%$ dari potensi yang ada (Widodo dkk., 2015).

Selain tongkol jagung, biomassa yang dapat digunakan sebagai bahan baku untuk membuat biopelet adalah ampas kelapa. Ampas kelapa merupakan biomassa yang berasal dari zat organik hasil perasan santan yang masih mengandung lemak yang dapat dikonversi menjadi energi (Hasanuddin \& Lahay, 2012). Ampas daging buah kelapa dan tongkol jagung belum termanfaatkan sepenuhnya, padahal kedua bahan tersebut merupakan biomassa dengan nilai kalor yang relatif besar (Wijianti dkk., 2017). Menurut Badan Pusat Statistik Sumatera Selatan (2015) produksi kelapa pada tahun 2015 mencapai 58.230,67 ton dengan luas lahan 68077,8 ha. Sehingga untuk ketersediaan bahan baku biopelet sangat melimpah.

Pembuatan biopelet dengan bahan baku campuran dari ampas kelapa dan tongkol jagung, bahan baku akan dipisahkan sesuai ukuran yang diinginkan dengan menggunakan sieving machine. Ukuran untuk masingmasing jenis bahan baku 60 mesh. Campuran ampas kelapa dan tongkol jagung yang terbaik yaitu $75 \%: 25 \%$ yang menghasilkan nilai kalor sebesar $6417,251 \mathrm{kal} / \mathrm{gr}$ (Wijianti dkk., 2017).

\subsection{Pendekatan Desain Fungsional}

Prototipe pengering skala laboratorium pada penelitian ini memiliki fungsi untuk mengurangi kadar air bahan baku dan produk biopelet. Bahan baku biomassa hasil pengeringan akan dijadikan biopelet, sehingga digunakan oven pengering dengan suplai panas dari furnace.

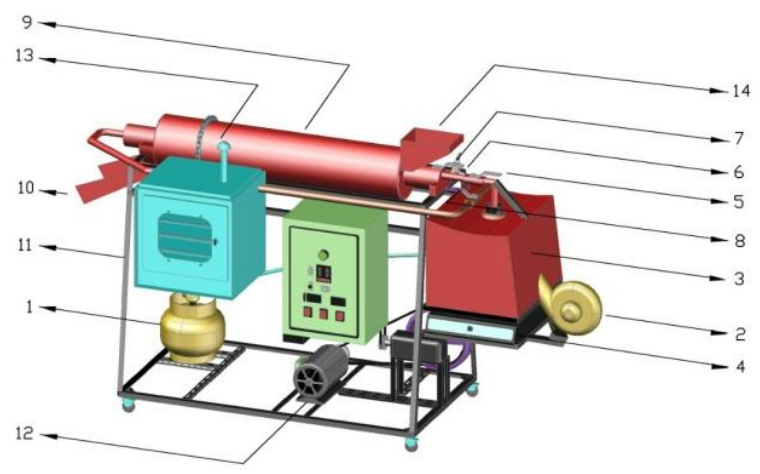

Gambar 1. Komponen Prototipe Alat Pengering
1. Valve 4

2. Silinder Putar

3. Feed out (umpan keluar)

4. Oven

5. Motor Listrik

6. Stack Gas

7. Feed in (umpan masuk)
8. Tabung gas LPG

9. Blower

10. Furnace

11. Kompor

12. Valve 1

13. Valve 2

14. Valve 3
Prototipe pengering yang dibuat memiliki komponenkomponen dengan fungsinya masing-masing, yaitu:

1. Tabung gas LPGs

Tabung gas LPG berfungsi menampung gas dalam kondisi bertekanan yang akan digunakan untuk peroses pembakaran.

2. Blower

Blower berfungsi menarik udara lingkungan untuk masuk ke ruang pemanasan dan menghembuskan udara panas menuju silinder putar.

3. Furnace

Berfungsi berfungsi sebagai tempat terjadinya pemanasan udara lingkungan yang akan digunakan sebagai udara pengering pada proses pengeringan.

4. Kompor gas

Kompor gas berfungsi untuk menghasilkan panas dengan bahan bakar LPG.

5. Valve 1

Valve 1 berfungsi untuk mengontrol kecepatan udara pengering yang akan digunakan.

6. Valve 2

Valve 2 berfungsi untuk melakukan pengecekan relatif humidity dan kecepatan udara pengering

7. Valve 3

Valve 3 berfungsi untuk mengontrol udara pengering masuk ke dalam silinder putar.

8. Valve 4

Valve 4 berfungsi untuk mengontrol udara pengering masuk ke dalam oven.

9. Silinder Putar

Silinder putar berfungsi sebagai ruang terjadinya proses pengeringan bahan baku dengan menggunakan udara panas secara kontak langsung yang dihasilkan dari furnace. 
10. Feed out

Feed out berfungsi sebagai tempat keluaran bahan baku yang telah dikeringkan dalam sillinder putar.

11. Oven

Oven berfungsi sebagai tempat pengeringan produk biopelet.

12. Motor Listrik

Motor listrik befungsi sebagai motor penggerak untuk memutar silinder dalam proses pengeringan.

13. Stack gas

Stack gas berfungsi sebagai tempat keluaran udara sisa pengeringan.

14. Feed in

Feed in berfungsi sebagai wadah masuk bahan baku yang akan dikeringkan.

\subsection{Pendekatan Desain Struktural}

Secara umum prototipe alat pengering ini terbagi menjadi 2 jenis, yang pertama yaitu pengering tipe putar berupa tabung silinder sebagai ruang pengering bahan baku biomassa yang dirancang dengan ukuran panjang tabung $75 \mathrm{~cm}$ dan diameter $15 \mathrm{~cm}$ (lihat Gambar 1). Di sisi sebelah kiri merupakan tempat masuknya udara panas dan umpan biomassa sedangkan di sisi sebelah kanan merupakan tempat keluarnya udara pemanas dan tempat keluarnya umpan, posisi ini dimanfaatkan agar udara panas langsung masuk kedalam silinder putar. Tabung silinder digerakkan oleh motor listrik dengan daya 300 watt dan yang kedua adalah oven dirancang berbentuk persegi panjang dengan ukuran $30 \times 30 \mathrm{~cm}$ yang digunakan untuk mengeringkan produk biopelet.

\subsection{Prosedur Penelitian}

Berikut disajikan prosedur kerja dalam proses penelitian.

\subsubsection{Preparasi Bahan Baku}

Menyiapkan bahan baku awal yaitu ampas kelapa dan tongkol jagung yang digunakan untuk pembuatan biopelet, kemudian melakukan pengecilan ukuran dengan menggunakan alat jaw crusher hingga ukuran bahan baku menjadi ukuran yang lebih kecil. setelah itu, mencampur bahan baku ampas kelapa dan tongkol jagung dengan perbandingan $75 \%: 25 \%$.

\subsubsection{Tahap Penentuan Massa $\mathrm{H}_{2} \mathrm{O}$ pada Udara Masuk Pengering}

Membuka valve $\left(\mathrm{V}_{1}\right)$ untuk mengatur bukaan laju alir udara pengering. Kemudian, menutup valve $\left(\mathrm{V}_{3}\right)$ aliran udara yang masuk ke silinder putar. Lalu, membuka valve $\left(\mathrm{V}_{2}\right)$ untuk mengukur kecepatan aliran udara pengering dengan menggunakan anemometer. Mencatat nilai Relative Humidity (RH) dan yang tertera di kontrol panel. Kemudian menentukan nilai humiditas berdasarkan nilai Relative Humidity (RH) dengan menggunakan Psychrometric Calculations Sugar Engineer. Menghitung massa $\mathrm{H}_{2} \mathrm{O}$ pada udara yang masuk ke pengering putar.

\subsubsection{Tahap Pengeringan Bahan Baku}

Menyiapkan campuran bahan baku sebanyak $0,2 \mathrm{~kg}$, memanaskan furnace dengan menghidupkan kompor LPG kemudian menyalakan blower untuk mengalirkan udara masuk ke dalam furnace. Setelah temperatur udara panas sudah mencapai temperatur yang diinginkan, selanjutnya membuka katup $\mathrm{V}_{1}$ dan $\mathrm{V}_{3}$ untuk mengalirkan udara panas tersebut menuju silinder putar. Selanjutnya menghidupkan motor listrik untuk memutar silinder, kemudian memasukan bahan baku sedikit demi sedikit selama 1 jam hingga bahan baku selesai dikeringkan. Menimbang bahan baku yang telah selesai dikeringkan hingga berat konstan dan menghitung kadar air yang dihasilkan.

\subsubsection{Tahap Perhitungan Massa $\mathrm{H}_{2} \mathrm{O}$ pada Udara Keluar Pengering Tipe Putar}

Tahap penentuan kadar air yang teruap ke udara adalah dengan mencatat nilai Relative Humidity (RH) yang tertera di kontrol panel. Kemudian menentukan nilai humiditas yang dihasilkan dari nilai Relative Humidity (RH) dengan menggunakan Psychrometric Calculations Sugar Engineer. Lalu menghitung massa $\mathrm{H}_{2} \mathrm{O}$ pada udara yang keluar dari pengering tipe putar.

\subsubsection{Tahap Pembuatan Biopelet}

Melakukan pengayakan bahan baku yang telah dikeringkan dengan alat sieving untuk mendapatkan ukuran +60 mesh. Setelah dilakukan pengayakan, menyiapkan massa campuran bahan baku sebanyak 40 gr. Kemudian melakukan pencetakan biopelet dengan menggunakan alat pencetak biopelet.

\subsubsection{Analisa Kadar Air Biopelet (ASTM D 3302M- 12)}

Analisa kadar air biopelet mengacu pada ASTM D 3302M-12.

\subsubsection{Analisis Nilai Kalor Biopelet (ASTM D 5865- 07a)}

Adapun untuk analisa nilai kalor, menggunakan alat bomb calorimeter tipe parr 6400

\subsection{Perhitungan}

Berikut merupakan perhitungan yang dilakukan dalam penelitian

\subsubsection{Densitas Udara Masuk dan Densitas Udara} Keluar

$$
\begin{aligned}
& \mathrm{PV}=\mathrm{nRT} \\
& \mathrm{P} \frac{m}{B M}=\mathrm{nRT}
\end{aligned}
$$

Dimana $\mathrm{P}$ adalah tekanan (atm), $\mathrm{V}$ adalah volume $\left(\mathrm{m}^{3}\right.$ atau $\mathrm{L}$ ), $\mathrm{m}$ adalah massa udara ( $\mathrm{gr}$ atau $\mathrm{kg}$ ), BM adalah berat molekul udara (gr/grmol), $\mathrm{n}$ adalah jumlah mol gas 
(gr/grmol atau $\mathrm{kg} / \mathrm{kgmol}$ ), $\mathrm{R}$ adalah konstanta gas (J/kmol K atau L atm/grmol K), dan T adalah suhu (K).

\subsubsection{Laju Alir Volumetrik Udara}

$$
\mathrm{Q}=\mathrm{v} \times \mathrm{A}
$$

Dimana Q adalah laju alir volumetric udara $\left(\mathrm{m}^{3} / \mathrm{s}\right.$ atau $\mathrm{L} / \mathrm{s})$, v adalah kecepatan aliran udara $(\mathrm{m} / \mathrm{s})$, dan A adalah luas penampang aliran udara $\left(\mathrm{m}^{2}\right)$.

\subsubsection{Massa Udara Masuk dan Massa Udara Keluar}

$$
\mathrm{m}_{\text {udara }}=\mathrm{Q} \times \rho
$$

Dimana Q adalah alir volumetric udara $\left(\mathrm{m}^{3} / \mathrm{s}\right.$ atau $\left.\mathrm{L} / \mathrm{s}\right), \rho$ adalah densitas udara pengering $\left(\mathrm{gr} / \mathrm{m}^{3}\right.$ atau $\left.\mathrm{gr} / \mathrm{L}\right)$, dan $\mathrm{m}$ adalah massa udara (gr atau $\mathrm{kg}$ ).

\subsubsection{Massa $\mathrm{H}_{2} \mathrm{O}$ yang Terkandung dalam Udara Masuk dan Keluar Drum Putar}

$$
\begin{aligned}
& \mathrm{m}_{1}=\omega_{\text {masuk drum }} \mathrm{x} \text { massa udara } \\
& \mathrm{m}_{2}=\omega_{\text {keluar drum }} \mathrm{x} \text { massa udara }
\end{aligned}
$$

Dimana $\mathrm{m}_{1}$ merupakan massa $\mathrm{H}_{2} \mathrm{O}$ yang terkandung dalam udara masuk $\left(\mathrm{kg} \mathrm{H}_{2} \mathrm{O}\right), \mathrm{m}_{2}$ adalah massa $\mathrm{H}_{2} \mathrm{O}$ yang terkandung dalam udara keluar $\left(\mathrm{kg} \mathrm{H}_{2} \mathrm{O}\right)$, dan $\omega$ adalah nilai humidity ( $\mathrm{kg} \mathrm{H}_{2} \mathrm{O} / \mathrm{kg}$ udara kering).

\subsubsection{Massa $\mathrm{H}_{2} \mathrm{O}$ yang Teruapkan ke Udara}

$$
\mathrm{m}_{\mathrm{H} 2 \mathrm{O}}=\mathrm{m}_{2}-\mathrm{m}_{1}
$$

Dimana $\mathrm{m}_{\mathrm{H} 2 \mathrm{O}}$ adalah massa $\mathrm{H}_{2} \mathrm{O}$ yang teruapkan ke udara.

\subsubsection{Panas $\mathrm{H}_{2} \mathrm{O}$ di Udara}

$$
\mathrm{Q}=\mathrm{n} \mathrm{Cp} \mathrm{dT}
$$

Dimana $\mathrm{n}$ adalah mol $\mathrm{H}_{2} \mathrm{O}$ yang teruapkan ke udara, $\mathrm{Cp}$ adalah kapasitas panas $\mathrm{H}_{2} \mathrm{O}$ dT adalah selisih antara temperatur udara masuk dan udara keluar

$\mathrm{Cp}=\mathrm{a}+\mathrm{bT}+\mathrm{cT}^{2}$

$\mathrm{Cp}_{2} \mathrm{O}=a+\frac{b}{2}\left(T_{2}+T_{1}\right)+\frac{b}{3}\left(T_{2}{ }^{2}+\left(T_{1} \times T_{2}\right)+T_{1}{ }^{2}\right)$

Dimana $\mathrm{Cp}$ H2O adalah kapasitas panas $\mathrm{H}_{2} \mathrm{O}$ $\left(\mathrm{gcal} / \mathrm{gmol}^{\mathrm{O}} \mathrm{K}\right), \mathrm{T}_{1}$ merupakan temperatur udara masuk $\left({ }^{\circ} \mathrm{K}\right), \mathrm{T}_{2}$ merupakan temperatur udara keluar $\left({ }^{\circ} \mathrm{K}\right)$, dan nilai a sebesar 7,136; b sebesar 2,640 × 10 $0^{-3}$; dan $\mathrm{c}$ sebesar $0,0459 \times 10^{-6}$.

\section{PEMBAHASAN}

Berikut disajikan hasil pengaruh kecepatan udara pengering terhadap massa dan panas $\mathrm{H}_{2} \mathrm{O}$ yang teruapkan ke udara

\subsection{Pengaruh kecepatan udara pengering terhadap massa $\mathrm{H}_{2} \mathrm{O}$ yang teruapkan ke udara}

Grafik pada gambar 2 menunjukkan pengaruh kecepatan udara pengering terhadap massa $\mathrm{H}_{2} \mathrm{O}$ yang teruapkan ke udara.

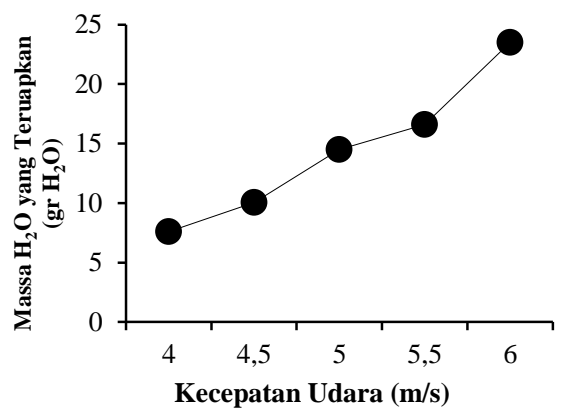

\section{Gambar 2. Grafik Kecepatan Udara Terhadap Massa $\mathrm{H}_{2} \mathrm{O}$ yang Teruapkan Ke Udara}

Gambar 2 menunjukkan semakin tinggi kecepatan udara panas yang disuplai maka semakin banyak massa $\mathrm{H}_{2} \mathrm{O}$ yang teruapkan oleh udara. Hal ini dikarenakan dengan kecepatan udara yang tinggi maka volume udara panas yang masuk ke pengering silinder putar lebih banyak dalam waktu konstan selama 1 jam. Bertambahnya kecepatan udara pengering akan meningkatkan difusi panas udara ke dalam butiranbutiran umpan sehingga meningkatkan jumlah air yang dapat diuapkan (Dwika dkk., 2012). Oleh karena itu semakin tinggi laju alir udara pengering maka proses pengeringan akan berjalan semakin cepat. Semakin besar volume udara yang mengalir maka akan semakin besar kemampuannya membawa dan menampung air dari permukaan bahan (Syahrul dkk., 2018).

Variasi kecepatan udara pengering $4 \mathrm{~m} / \mathrm{s}$ menghasilkan massa $\mathrm{H}_{2} \mathrm{O}$ teruapkan oleh udara sebesar 7,6 gr dan untuk kecepatan udara 4,5 m/s menghasilkan massa $\mathrm{H}_{2} \mathrm{O}$ yang teruapkan oleh udara sebesar 10,06 gr. Sedangkan pada kecepatan $5 \mathrm{~m} / \mathrm{s}$ mengalami peningkatan hasil massa $\mathrm{H}_{2} \mathrm{O}$ yang teruapkan oleh udara yaitu sebesar 14,5 gr dan untuk kecepatan $5,5 \mathrm{~m} / \mathrm{s}$ pun mengalami peningkatan hasil massa $\mathrm{H}_{2} \mathrm{O}$ yang teruapkan menjadi sebesar 16,6 gr. Pada kecepatan $6 \mathrm{~m} / \mathrm{s}$ menghasilkan massa $\mathrm{H}_{2} \mathrm{O}$ yang teruapkan paling tinggi yaitu sebesar $23,5 \mathrm{gr}$.

\subsection{Pengaruh kecepatan udara pengering terhadap panas $\mathrm{H}_{2} \mathrm{O}$ yang teruapkan ke udara}

Grafik pada gambar 3 menunjukkan pengaruh kecepatan udara pengering terhadap panas $\mathrm{H}_{2} \mathrm{O}$ yang teruapkan ke udara 


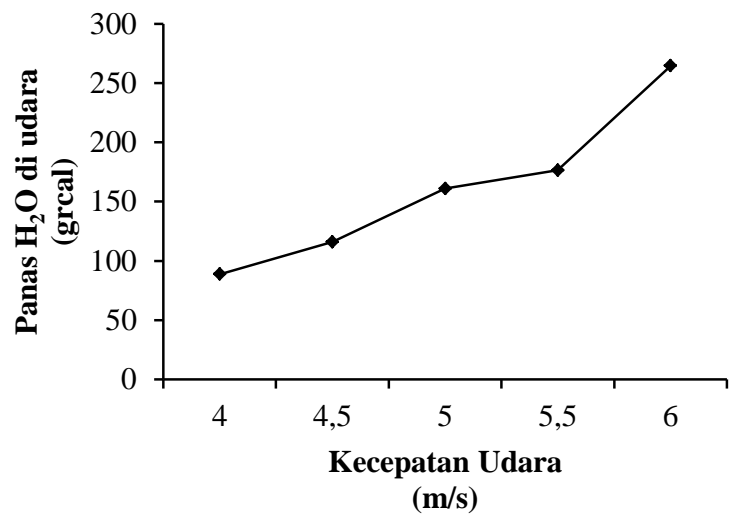

Gambar 3. Grafik Kecepatan Udara Terhadap Panas $\mathrm{H}_{2} \mathrm{O}$ di Udara

Dari gambar 3 terlihat bahwa hasil panas $\mathrm{H}_{2} \mathrm{O}$ di udara mengalami kenaikan seiring dengan bertambahnya kecepatan udara pengering. Dimana hubungan antara kecepatan udara dan panas $\mathrm{H}_{2} \mathrm{O}$ di udara yaitu semakin tinggi kecepatan udara panas yang disuplai maka semakin tinggi panas $\mathrm{H}_{2} \mathrm{O}$ di udara. Hal ini dikarenakan kecepatan udara mempengaruhi hasil massa $\mathrm{H}_{2} \mathrm{O}$ yang teruapkan, dimana dengan semakin tinggi hasil massa $\mathrm{H}_{2} \mathrm{O}$ yang teruapkan maka semakin tinggi pula panas $\mathrm{H}_{2} \mathrm{O}$ di udara. Kemampuan untuk menguapkan air akan bertambah besar dengan bertambah banyaknya jumlah udara panas yang masuk, penguapan tersebut diakibatkan karena terjadinya perbedaan tekanan uap antara bahan dan uap air diudara. Semakin besar kecepatan aliran udara pengering maka semakin banyak massa uap air yang dipindahkan dari bahan ke udara maka panas $\mathrm{H}_{2} \mathrm{O}$ di udara yang di hasilkan juga semakin tinggi.

Variasi kecepatan udara $4 \mathrm{~m} / \mathrm{s}$ menghasilkan panas $\mathrm{H}_{2} \mathrm{O}$ di udara sebesar 88,74 grcal dan kecepatan udara $4,5 \mathrm{~m} / \mathrm{s}$ menghasilkan panas $\mathrm{H}_{2} \mathrm{O}$ di udara sebesar 116,01 grcal. Selanjutnya pada kecepatan udara $5 \mathrm{~m} / \mathrm{s}$, panas $\mathrm{H}_{2} \mathrm{O}$ di udara mengalami kenaikan menjadi sebesar 160,98 grcal dan begitupun pada kecepatan $5,5 \mathrm{~m} / \mathrm{s}$ panas $\mathrm{H}_{2} \mathrm{O}$ di udara mengalami kenaikan menjadi 176,35 $\mathrm{m} / \mathrm{s}$. Pada kecepatan udara $6 \mathrm{~m} / \mathrm{s}$, menghasilkan panas $\mathrm{H}_{2} \mathrm{O}$ di udara paling tinggi yaitu sebesar 264,55 grcal.

\subsection{Analisa Kadar Air dan Nilai Kalor Biopelet}

Dari hasil panas $\mathrm{H}_{2} \mathrm{O}$ di udara paling tinggi maka dibuat produk biopelet serta ditentukan nilai kadar air dan menganalisa nilai kalor produk biopelet tersebut. Hasil panas $\mathrm{H}_{2} \mathrm{O}$ di udara paling tinggi yaitu sampel pada kecepatan $6 \mathrm{~m} / \mathrm{s}$. Dari hasil analisa kadar air diperoleh nilai kadar air biopelet sebesar $6,47 \%$ dan nilai kalor sebesar 4655,0668 cal/gr. Parameter utama dalam menentukan kualitas bahan bakar biopelet adalah nilai kalor pembakaran. Nilai kalor didefenisikan sebagai panas yang dilepaskan dari pembakaran sejumlah kuantitas unit bahan bakar (massa) dimana produknya dalam bentuk ash, gas CO2, SO2, Nitrogen dan air, tidak termasuk air yang menjadi uap (vapor). Kalor yang semakin tinggi menunjukan kualitas bahan bakar yang semakin baik (Damayanti dkk., 2017). Hasil analisa kadar air dan nilai kalor biopelet menunjukkan bahwa kadar air dan nilai kalor produk biopelet hasil penelitian ini telah memenuhi standar SNI 8021-2014 yaitu kadar air $\leq 12 \%$ dan nilai kalor sebesar minimal $4000 \mathrm{cal} / \mathrm{gr}$.

\section{KESIMPULAN}

Pengeringan merupakan suatu proses yang penting dalam pembuatan biopelet, hal ini karena proses pengeringan merupakan proses perpindahan panas dari sebuah permukaan bahan sehingga kandungan air pada permukaan bahan berkurang. Pengeringan dengan menggunakan alat pengering tipe putar merupakan salah satu alternatif untuk proses pengeringan bahan baku biopelet ampas kelapa dan tongkol jagung. Salah satu factor yang mempengaruhi saat proses pengeringan adalah kecepatan volumetrik, sehingga dilakukan pengeringan dengan variasi kecepatan udara pengering. Biopelet akan dilakukan analisa kadar air dan nilai kalor, hal ini dilakukan untuk mengetahui kualitas biopelet sudah memenuhi SNI 8021-2014.

Setelah dilakukan pengeringan tersebut maka dapat terlihat hasil perhitungan massa $\mathrm{H}_{2} \mathrm{O}$ yang teruapkan paling banyak ke udara sebesar 23,5 gr pada kecepatan udara $6 \mathrm{~m} / \mathrm{s}$. Panas $\mathrm{H}_{2} \mathrm{O}$ di udara paling tinggi yang teruapkan ke udara sebesar 264,55 grcal pada kecepatan yang sama dengan massa $\mathrm{H}_{2} \mathrm{O}$ yaitu $6 \mathrm{~m} / \mathrm{s}$, hal ini disebabkan karena pengaruh massa $\mathrm{H}_{2} \mathrm{O}$ di udara. Dari gambar 2 dan 3 terlihat bahwa semakin tinggi kecepatan udara pengering maka semakin besar massa $\mathrm{H}_{2} \mathrm{O}$ yang teruapkan ke udaran serta panas $\mathrm{H}_{2} \mathrm{O}$ akan semakin tinggi. Kadar air dan nilai kalor produk biopelet hasil penelitian ini sesuai dengan SNI 8021-2014 yaitu sebesar $6,47 \%$ dan $4655,0668 \mathrm{cal} / \mathrm{gr}$.

\section{SARAN}

Dari penelitian yang telah dilakukan, massa $\mathrm{H}_{2} \mathrm{O}$ paling tinggi dari bahan baku biopelet yang teruapkan ke udara masih tergolong sedikit, maka perlu untuk memperhatikan hal-hal yang berkaitan dengan desain dan pengoperasian alat khususnya pada drum putar. selain itu, perlu dilakukan penelitian lanjutan dengan menggunakan metode perpindahan panas secara direct heat-counter current flow.

\section{DAFTAR PUSTAKA}

Badan Pusat Statistik (BPS) Provinsi Sumatera Selatan. 2015. https://sumsel.bps.go.id

Damayanti, R., Lusianal, N., \& Prasetyo, J. 2017. Studi Pengaruh Ukuran Partikel Dan Penambahan Perekat Tapioka Terhadap Karakteristik Biopelet Dari Kulit Coklat (Theobroma Cacao L.) Sebagai Bahan Bakar Alternatif Terbarukan. Teknotan, 11(1), 2528-6285.

Dwika, R. T., Ceningsih, T., \& Sasongko, S. B. 2012. Pengaruh Suhu dan Laju Alir Udara Pengering pada Pengering Keraginan Menggunakan 
Teknologi Spray Dryer. Teknologi Kimia dan Industri, 1(1), 298-304.

Jaelani, A. 2017. Kebijakan Energi Baru Terbarukan di Indonesia: Isyarat Ilmiah Al-Qur'an dan Implementasinya dalam Ekonomi Islam. MPRA (83314)

Kartika, S. A. 2017. Analisis Konsumsi Energi dan Program Konservasi Energi (Studi Kasus : Gedung Perkantoran dan Kompleks Perumahan TI). (30), 41-51.

Lamanda, D. D., Setyawati, D., Murhaida, Diba, F., \& Roslinda, E. 2015. Karakteristik Biopelet Berdasarkan Komposisi Serbuk Batang Kelapa Sawit dan Arang Kayu Laban dengan Jenis Perekat Sebagai Bahan Bakar Alternatif Terbarukan. Hutan Lestari, 3(2), 313-321.

Mahdie, M. F., Subari, D., Sunardi, \& Ulfah, D. 2016. Pengaruh Campuran Limbah Kayu Rambai dan Api-api Terhadap Kualitas Biopelet Sebagai Energi Alternatif dari Lahan Basah. Hutan Tropis, 4(3), 246-253.

Pradipta, A. L. V., \& Kosasih, I. E. A. 2014. Pengaruh Laju Aliran, Temperatur dan Kelembaban Udara Terhadap Laju Pengeringan Keping Singkong. 110.

Stefanus, M., \& Kosasih, I. E. A. 2014. Pengaruh kelembaban, laju aliran dan temperatur udara pengering terhadap laju pengeringan gula aren. $1-7$.

Syahrul, S., Romdhani, R., \& Mirmanto, M. 2018. Pengaruh variasi kecepatan udara dan massa bahan terhadap waktu pengeringan jagung pada alat fluidized bed. Dinamika Teknik Mesin, 6(2), 119126. https://doi.org/10.29303/d.v6i2.15

Utami, B. 2017. Making Charcoal Briquettes from Corncobs Organic Waste Using Variation of Type and Percentage of Adhesives Making Charcoal Briquettes from Corncobs Organic Waste. (May). https://doi.org/10.20961/jkpk.v2i1.8518

Widodo, T. W., Asari, A., \& Elita, A. N. (n.d.). Bio Energi Berbasis Jagung dan Pemanfaatan Limbahnya Bio- Energy ( Corn based) and The Utilization Its Waste. 1-13.

Wijianti, E. S., Setiawan, Y., \& Wisastra, H. 2017. Briket Arang Berbahan Campuran Ampas Daging Buah Kelapa dan Tongkol Jagung. Jurnal Teknik Mesin, 3(1), 2502-2040.

Zikri, A., Erlinawati, \& Rusnadi, I. 2015. Uji Kinerja Rotary Dryer Berdasarkan Efisiensi Termal Pengeringan Serbuk Kayu untuk Pembuatan Biopelet. Teknik Kimia, 21(2), 50-58. 